\title{
PENGARUH BEBAN KERJA TERHADAP KINERJA PERAWAT DENGAN MODEL SWAT (SUBJECTIVE WORKLOAD ASSESSMENT TECHNIQUE) DI RUANG RAWAT INAP RUMAH SAKIT UMUM DELIMA MEDAN TAHUN 2019.
}

\section{The Effect Of Workload On Nurse Performance With The Subjective Workload Assessment Technique In The Hospital Inpatient Room Of Medan Pomegranate General Hospital In 2019.}

\author{
${ }^{1}$ Muttaqin Al Ridha, ${ }^{2}$ Arifah Devi Fitriani, ${ }^{3}$ Megawati \\ 1,2,3 Institut Kesehatan Helvetia, Jl. Kapten Sumarsono No. 107, Medan 20124 \\ ${ }^{1}$ muttaqin.alridha@gmail.com, ${ }^{2}$ arifahdevifitriani@ helvetia.ac.id, ${ }^{3}$ hjmegawati19632gmail.com
}

\begin{abstract}
Abstark - Peneliti memiliki harapan yang besar bahwa dengan Model Seperti SWAT (Subjective Workload Assessment Technique) di Ruang Rawat Inap Rumah Sakit Delima Medan (2019). Penelitian ini di harapkan dapat memberikan masukan tentang pengaruh faktor keseimbangan beban kerja yang dipersepsi subjektif oleh perawat rawat inap, memberikan perbaikan pada hasil Kinerja yang terpengaruhi secara optimal.

Penelitian ini adalah penelitian survey bersifat analitik eksploratory dengan menggunakan rancangan cross sectional yang berciri khas yaitu menemukan data primer yang sedang dialami responden pada waktu wawancara dilaksanakan. Penelitian ini dilakukan di RSU Delima J1 KL Yos Soedarso KM 13,6 Simpang Martubung Medan.Populasi dalam penelitian ini adalah 64 orang. Responden yang terpilih atau tersisihkan melalui proses adalah yang sudah berpengalaman lebih dari 3 bulan masa percobaan perawat. Sampel dalam penelitian ini adalah 64 orang perawat rawat inap.

Hasil Penelitian menunjukkan ada hubungan antara 4 subvariabel biodata dengan kinerja, berkorelasi signifikan $(\alpha<0,05)$, memiliki korelasi rendah s/d tinggi ( $p=>0,115 \mathrm{~s} / \mathrm{d} 0,817)$, kecuali oleh subvariabel kelompok umur. Nilai kinerja diukur secara dikotomi dari nilai $1-16$ pencapaian kriteria CARE. Penilaian akhir menunjukkan hasil perumusan regresi logistik dari kriteria kinerja responden : Y = - 11.309 + 1.125 Rasio Beban Mental. Dengan sederhana ditunjukkan bahwa RBM (Beban Mental) adalah variabel yang berkaitan signifikan dengan kinerja / karakteristik CARE pada keperawatan.

Kesimpulan dalampenelitian ini menunjukkan adanya peningkatan pencapaian kinerja dengan indikator kenaikan BOR ke 75\% di unit rawat inap. Hal tersebut terkait dengan kualitas CARE pada petugas yang dievaluasi dengan karakteristik CARE. Hal tersebut telah diungkapkan dengan regresi logistik. Saran. Lanjutkan pengembangan mutu petugas keperawatan dengan : a). memelihara kenyamanan mentalitas; b) terus melengkapi fasilitas serta c) melaksanakan pelatihan kerja yang cukup dan konsisten
\end{abstract}


Journal of Healthcare Technology and Medicine Vol. 6 No. 2 Oktober 2020

Universitas Ubudiyah Indonesia

e-ISSN : 2615-109X

\section{PENDAHULUAN}

Profesi perawat di RS dapat dikatakan $50 \%$ mendominasi tugas-tugas pelayanan di RS Delima. Menurut penelitian terdahulu. Jumlah perawat di sana terdaftar sebanyak 60 perawat dengan latar belakang > $60 \%$ adalah tamatan Akademi Kebidanan. Jumlah perawat tidak konsisten sepanjang bulan karena setiap bulannya ada sejumlah perawat yang keluar dan masuk dari dan ke kelompok perawat di unit rat inap. Jumlah mereka secara ideal mencukupi bila saja semuanya bekerja di unit rawat inap dengan jumlah tempat tidur sekitar 80 tempat tidur. Sejumlah 20 orang bekerja di bagian lain di perawatan RS. (11)

Pergerakan keluar masuk perawat dari atau ke RS membuat beban kerja standar menjadi selalu bervariasi naik turun di sekitar 70 persen dari yang ideal. Pengetahuan dan pelayanan mereka juga tidak berada di dalam tingkat yang standar dan kondisi ini dapat menambah beban kerja relatif meningkat menjadi lebih berat sementara tuntukan program akreditasi memang sejak awal tetap menambah beban karena perbaikan-perbaikan prosedur kerja menjadi baru. Pada saat yang sama disebutkan pada penelitian itu bahwa kebutuhan dari personal perawat yang rata-rata membuat RS Delima, hanya sebagai batu loncatatan menunggu kesempatan menjadi pegawai negeri, membuat motivasi para perawat menjadi terbagi-bagi, relatif menambah berat beban kerja.

Pengukuran Beban Kerja Perawat Menggunakan Metode NASA TLX (National Aeronautics and Space Administration Task Load Index). Pemakaian teori ini di Rumah Sakit" oleh T Fariz Hidayat di FT USU. Ia menyatakan bahwa Perkembangan teknologi yang semakin canggih membuat masyarakat pengguna jasa pelayanan kesehatan lebih memilih pelayanan yang praktis, pelayanan yang bermutu, sarana dan prasarana yang lengkap dan tenaga kerja yang berkualitas dan professional. Rumah Sakit perlu melakukan pengukuran beban kerja dikarenakan jumlah pengunjung dari tiap tahun mengalami kenaikan rata - rata $8 \%$ pada tiap poliklinik.

Dampak psikis yang terjadi akibat perawat harus melayani pasien yang berlebih seperti perawat menjadi gampang marah kepada pasien dan perawat bekerja dengan tergesa-gesa dalam melayani pasien. Penelitian ini bertujuan untuk mengukur beban kerja mental perawat pada instalasi rawat jalan Rumah Sakit.

Peneliti memiliki harapan yang besar bahwa dengan Model Seperti SWAT (Subjective Workload Assessment Technique) di Ruang Rawat Inap Rumah Sakit Delima Medan (2018). 
Journal of Healthcare Technology and Medicine Vol. 6 No. 2 Oktober 2020

Universitas Ubudiyah Indonesia

e-ISSN : 2615-109X

Penelitian ini di harapkan dapat memberikan masukan tentang pengaruh faktor keseimbangan beban kerja yang dipersepsi subjektif oleh perawat rawat inap, memberikan perbaikan pada hasil Kinerja yang terpengaruhi secara optimal.

\section{TINJAUAN PUSTAKA}

Faktor-faktor yang mempengaruhi Kinerja individu menurut Cokroaminoto (June 2007) bahwa Kinerja adalah nilai penampilan hasil kerja pegawai, baik secara kuantitas maupun kualitas. Kinerjamenurut Cokroaminoto dapat berupa penampilan kerja perorangan maupun kelompok (mengutip Ilyas, 1993). Kinerja organisasi merupakan hasil interaksi yang kompleks dan agregasi Kinerja sejumlah individu dalam organisasi.Untuk mengetahui faktor yang mempengaruhi (determinan) Kinerja individu, perlu dilakukan pengkajian terhadap teori Kinerja. Secara umum faktor fisik dan non fisik sangat mempengaruhi.

Pembuat Renstra membuat perencanaan secara bertahap yaitu rencana tahapan 5 tahun untuk jangka menengah dan rencana tahapan 1 tahun untuk jangka pendek. Renstra jangka menengah dan jangka pendek adalah bagian dari master program yang sebenarnya dibuat untuk mengisi plot renstra jangka panjang. Pada prinsipnya renstra renstra tersebut dibuat merupakan gambaran langkah-langkah strategis manajemen untuk selanjutnya menghasilkan visi dan misi pelayanan organisasi.

Penyusunan Rencana Strategis dimaksudkan sebagai pedoman untuk penyelenggaraan dan pengembangan Rumah sakit dalam jangka waktu tertentu, misalnya 5 tahun ke depan. Suatu prinsip penting di dalam pelaksanaan pedoman adalah sebagai garis besar tentang hal-hal yang sudah terpikirkan pada awal pembuat rencana. Rencana Strategis ini bukanlah merupakan pedoman yang statis yang mesti dilaksanakan walau apapun kejadian atau kondisi yang dialami pada suatu waktu di dalam tahapan, melainkan dibuat fleksibel dan dinamis.

Pemakai istilah "Subjektif" dalam SWAT adalah positif memudahkan pengukuran logis pada penelitian Beban Kerja dan Kompetensi Kerja pada setiap orang personel yang beraneka ragam .Pengukuran itu tergantung sepenuhnya pada penalaran dan pengakuan setiap personel berdasarkan nilai-nilai subjektif (menurut pandangan sendiri oleh informan/responden). 
Journal of Healthcare Technology and Medicine Vol. 6 No. 2 Oktober 2020

Universitas Ubudiyah Indonesia

e-ISSN : 2615-109X

\section{METODE PENELITIAN}

Penelitian ini adalah penelitian survey bersifat analitik eksploratory dengan menggunakan rancangan cross sectional (potong lintang) yang berciri khas yaitu menemukan data primer yang sedang dialami responden pada waktu wawancara dilaksanakan. Penelitian data primer tersebut tidak mempertanyakan hal - hal yang sudah berlalu dan tidak mempertanyakan hal-hal yang diprediksi untuk masa mendatang dari responden.

Penelitian ini dilakukan di RSU Delima) J1 KL Yos Soedarso KM 13,6 Simpang Martubung Medan

Populasi dalam penelitian ini adalah semua petugas keperawatan di unit rawat inap yang telah mengalami rutin kerja shift. Angka populasi adalah 67 orang. Responden yang terpilih (inklusi) atau tersisihkan melalui proses adalah yang sudah berpengalaman lebih dari 3 bulan masa percobaan perawat.

Metode pengukuran yang dilakukan dalam penelitian dibuat untuk memenuhi kewajban membuat penyederhanaan model pengukuran kuesioner yang berikan pada responden tentang nilai-nilai yang dibuat. Penilaian ini sering menjadi perbincangan atau perdebatan yang berkepanjangan karena penilaian pada kuesioner yang bersifat kualitatif, hanya mudah dapat dilaksanakan dalam ukuran skala ordinal ataupun nominal, padahal dalam aplikasi perhitungan nilai statistik parametrik seperti regresi (pengaruh) peneliti membutuhkan nilai kuantitatif atau sejenis rasio atau interval. Pendapat ini disetujui oleh Prof Sugiyono dan Prof Hadi Sutrisno. 
Journal of Healthcare Technology and Medicine Vol. 6 No. 2 Oktober 2020 Universitas Ubudiyah Indonesia

e-ISSN : 2615-109X

Tabel. 3.3. Aspel: Pengukuran Variabel Dependen dan Independen

\begin{tabular}{|c|c|c|c|c|c|c|}
\hline No & Variabel Independout & $\begin{array}{c}\text { Jumlah } \\
\text { Pemyata } \\
\text { an } \\
\end{array}$ & $\begin{array}{l}\text { Cara dau } \\
\text { Alat Ulur }\end{array}$ & $\begin{array}{c}\text { Slala } \\
\text { Pengukuran }\end{array}$ & Value & $\begin{array}{l}\text { Jenis } \\
\text { Slkala } \\
\text { Ukur } \\
\end{array}$ \\
\hline 1 & Jenis kelamin & 1 & Kuesioner & $\begin{array}{l}\text { Perempuan } \\
\text { Laki-laki }\end{array}$ & $\begin{array}{l}1 \\
2\end{array}$ & Nominal \\
\hline 2 & Kelompol Unur & 1 & Kuesioner & $\begin{array}{l}>20-35 \text { thn } \\
>35-50 \text { thn } \\
>50 \text { thn }\end{array}$ & $\begin{array}{l}1 \\
2 \\
3\end{array}$ & Nominal \\
\hline 3 & Pendidikan & 1 & Kuensioner & $\begin{array}{l}\text { SPK } \\
\text { Bederajat } \\
\text { D3bidan } \\
\text { Keperawatan }\end{array}$ & $\begin{array}{l}1 \\
2 \\
3\end{array}$ & Nominal \\
\hline 4 & Pengalaman Keja & 1 & Kuensioner & $\begin{array}{l}<1 \text { thn } \\
>1-2 \text { thn } \\
>3 \text { thn }\end{array}$ & $\begin{array}{l}1 \\
2 \\
3\end{array}$ & Nominal \\
\hline 5 & Persepsi pada Profesi & 1 & Kuensioner & $\begin{array}{l}\text { Kurang } \\
\text { Sedang } \\
\text { Baik: }\end{array}$ & $\begin{array}{l}1 \\
2 \\
3\end{array}$ & Nominal \\
\hline 6 & Beban keja & 5 & Kuesioner & $\begin{array}{l}\text { Kurang(1-5) } \\
\text { Sedang(6-10) } \\
\text { Baik(11-15) }\end{array}$ & $\begin{array}{l}1 \\
2 \\
3\end{array}$ & Ordinal \\
\hline 7 & $\begin{array}{c}\text { Beban Mental } \\
\text { Psilologi }\end{array}$ & 5 & Kuesioner & $\begin{array}{l}\text { Kurang }(1-5) \\
\text { Sedang(6-10) } \\
\text { Baik(11-15) }\end{array}$ & $\begin{array}{l}1 \\
2 \\
3\end{array}$ & Ordinal \\
\hline 8 & Keculapan Fasilitas & 5 & Kuesioner & $\begin{array}{l}\text { Kurang }(1-5) \\
\text { Sedang(6-10) } \\
\text { Baik(11-15) }\end{array}$ & $\begin{array}{l}1 \\
2 \\
3\end{array}$ & Ordinal \\
\hline No & Variabel Dependent & $\begin{array}{l}\text { Jumlah } \\
\text { Pernyataan }\end{array}$ & $\begin{array}{l}\text { Cara dan } \\
\text { Alat Ukur }\end{array}$ & $\begin{array}{c}\text { Skala } \\
\text { Pengukuran }\end{array}$ & Value & $\begin{array}{l}\text { Jenis } \\
\text { Skala } \\
\text { Ukur }\end{array}$ \\
\hline 1 & Kinerja & 16 & $\begin{array}{l}\text { Kuesioner } \\
\text { dan } 4 \\
\text { subvariabel } \\
\text { CARE }\end{array}$ & $\begin{array}{l}\text { Kurang }(1-10) \\
\text { Baik(11-16) }\end{array}$ & $\begin{array}{l}0 \\
1\end{array}$ & Interval \\
\hline
\end{tabular}


Journal of Healthcare Technology and Medicine Vol. 6 No. 2 Oktober 2020

Universitas Ubudiyah Indonesia

e-ISSN : 2615-109X

\section{HASIL PENELITIAN DAN PEMBAHASAN}

Seluruh 64 orang responden yaitu perawat dan bidan sebagai petugas pelayanan di unit rawat inap berkenan mengisi biodata mereka ke dalam setiap kolom jawaban sebagai berikut: Semuanya berjumlah 64 orang terinklusi sementara 3 orang sisanya tidak memenuhi syarat untuk dijadikan responden. Jumlah petugas dengan gender wanita sebanyak 58 orang sementara 6 orang lainnya adalah pria.

Beban fisik pelayanan yang diminta supaya ditanggapi dan dinilai oleh pihak petugas apakah terlalu ringan, sesuai atau terlalu berat dengan kondisi individu di setiap kelompok Peneliti memberi kode RBP (Beban Kerja Fisik dengan nilai Interval) untuk Variabel Beban Fisik. Kode ini hanya untuk memudahkan penjelasan analisis. Nilai RBP dikuantifikasi dari apa yang telah dinilai oleh responden di masing-masing 5 pertanyaan yang ditulis di kelompok variabel RBP tersebut. Pengukuran skala RBP dikuantifikasi supaya dapat memenuhi syarat hitung parametrik. Caranya nilai dari 5 nilai subvariabel yang dinilai oleh responden dalam 3 skala ordinal "1 (Buruk), 2 (Sedang) dan 3 (Baik). Nilai yang diberikan responden akan dijumlahkan. Jumlah tersebut kemudian dibagi 5 untuk mendapatkan nilai rata-rata. Nilai rata-rata tersebut dijadikan dikonversi menjadi nilai interval pada RBP. Regresi multivariat kemudian dapat memberikan hasil yang valid membuktikan nilai pengaruh regresi variabel independen terhadap variabel dependen. Hal serupa telah direncanakan untuk 3 variabel independen lain yatu: RBM (kode untuk Beban Psikologis); RBF (kode untuk Fasilitas dan Pelatihan). Sebagi variabel dependen yaitu variabel dependen dengan nama CARE (kode untuk Kinerja perawat/bidan)

Pada ulasan di alinea ini yang dipaparkan adalah nilai univariat dari nilai-nilai anak variabel dari 4 variabel yang telah disebut di atas yaitu anak-anak variabel (RBP, RBM, RBF dan CARE).

Bedasarkan hasil Asumsi akhir. Asumsi nilai kinerja di unit rawat inap RSU Delima Medan (lokasi penelitian) dipandang dari 3 determinan variabel independen Beban Pisik (Physik Pekerjaan), Beban Mental (Rasio Mental Psikologis) dan Beban Fasilitas (Rasio Kondisi Fasilitas dan Pelatihan 11) dapat dipengaruhi akurat di tingkat 56,8 \% (nilai Nagelkerke R. Square).

Tidak semua variabel independen dapat dipakai dalam perumusan terakhir kecuali faktor variabel Beban Mental. Temuan nilai yang dipaparkan pada tabel di atas bahwa hanya 
Journal of Healthcare Technology and Medicine Vol. 6 No. 2 Oktober 2020

Universitas Ubudiyah Indonesia

e-ISSN : 2615-109X

Faktor Variabel Beban Mental yang signifikan dapat diterima bermakna untuk perumusan regresi yaitu dengan nilai signifikansi $0,014<0,05$. Hipotesa kerja pada variabel ini menerima hipotesa kerja ada pengaruh terhadap perubahan nilai Kineja. Odds Ratio yang ditampilkan oleh SPSS untuk variabel Beban Mental juga cukup kuat melebihi nilai 3,079, artinya bahwa pengaruh dari variabel Beban Mental sangatlah kuat mencapai nilai 3 kali lebih kuat.

Pekerjaan evaluasi kualitas pengembangan juga dilakukan bersama-sama dengan rekanan kerja dari RS lain dan hal ini menjadi terjalin lebih kondusif karena RSU Delima yang adalah tipe C diharapkan rekanan RS tipe B dapat bekerja sama melaksanakan kinerja rujukan pasien secara seksama menurut ketentuan yang diterapkan oleh KARS maupun BPJS. Hasilnya untuk beberapa tahun kemudian (>2012), tampak ada perubahan signifikan memberi manfaat pada kinerja RSU Delima. Terkai dengan penelitian ini maka manfaat yang disorot dalam penelitian ini dipaparkan dengan sederhana di Bab IV mulai dari alinea 4.1 dan slanjutnya.

1. RSU Delima membenahi maslah orgnisasi internal. Pada awal 2010 struktur organisasi yang semula dicontohkan dengan sesederhana 3 departemen, Pelayanan Medis/Keperawatan/ Pelayanan Administrasi dan REkam Medis serta Pelayanan Perbendaharaan Keuangan, dikembangkan menjadi lebih lengkap menyongsong struktur organisasi RS tipe B. Sampai pada saat penelitian dilakukan struktur organisasi tersebut, sekalipun masih dijabat secara rangkap (organisasi dikelola secara lebih ramping), struktur masih tetap dipakai sebagai target pada masa berikut. Kelengkapan struktur dengan penjabat yang sudah diperlukan secara bertahap diisi oleh pengembang sumber daya manusia.

Pengisian jabatan dalam struktur organisasi RS, rekrutmen, pelatihan dilaksanakan secara profesional mencapai tingkat manfaat yang efisien dan efektif menurut keperluan strategis.

2. Tingkat pelayanan standar dipertahankan supaya meningkat, memberikan tingkat kepuasan pasien, keselamatan dan kenyamanan pasien dari masalah kecederaan ataupun malpraktek. Manajemen mengikuti prinsip program uji akreditasi RS.

3. Hasil nyata diperoleh dengan semakin naiknya nilai BOR penghunian RS mengikuti semakin baiknya rekomendasi BPJS melihat pembenahan departemen keperawatn rawat inap atas peningkatan desain dan kenyamanan pelayanan rawat inap. Pada saat ini BOR rata-rata di tingkat $70 \%$ atau lebih.

4. Tingkat keluar perawat dalam periode menjadi menipis hanya 1 atau 2 per bulan. 
Journal of Healthcare Technology and Medicine Vol. 6 No. 2 Oktober 2020

Universitas Ubudiyah Indonesia

e-ISSN : 2615-109X

5. Sistem informasi Rumah Sakit dikerjakan dengan konsisten sehingga dapat memberikan rumah sakit kepercayaan baik oleh pihak masyarakat pengguna jasa rawat inap maupun pihak pembuat keputusan strategi rumah sakit.

6. Pelatihan pelaksana pelayanan trutama kelompok perawat dan bidan yang gertugas di rawat inap diberi secukupnya pelatihan mengikuti temuan hasil evaluasi kerja terhadap kinerja petugas.

7. Sistem pengupahan dan kompensasi lain yang sebelumnya masih kurang terperhatikan sudah mulai dibenahi secara berangsur dan menurut kondisi rumah sakit pada umumnya di daerah ini. Masalah ini tidak serempak dapat dilakukan segera tetapi secara berangsur dan dapat dilaksnakan oleh bagian keuangan rumah sakit.

\section{KESIMPULAN}

1. Tidak ada pengaruh satupun dari 5 variabel Biodata yang secara statistic dapat dikatakan valid memengaruhi sepihak terhadap Kinerja pelayanan petugas perawat ataupun bidan di unit rawat inap. Pengukuran biodata yang dipakai pada penelitian untuk variable biodata adalah skala nominal ataupun skala ordinal. Kedua jenis skala tersebut tidak dapat diproses dengan statistik parametrik regresi. Analisis pengaruh timbal balik (arahnya tidak tertentu) hanya dapat diprediksi menggunakan analisis korelasi yang menggambarkan adanya kemungkinan keterkaitan nilai-nilai di antara kedua variable yang difokus. Hasil uji korelasi nilai antara 5 variabel biodata dengan nilai variabel Kinerja dipaparkan sebagai berikut :

1) Korelasi variabel Kelompok Umur dengan Kinerja berkoefisien 0,141 (kecil) dan kebermaknaannya lemah $=0,266(>0,05)$

2) Korelasi variabel Kelompok Pendidikan untuk pendidikan berkoefisien 0,707 (besar) dan tingkat kebermaknaannya baik yaitu 0,00 $(<0,05$.

3) Korelasi variabel Kelompok Pengalaman untuk pengalaman kerja di rawat inap berkoefisien 0,453 (lemah) tetapi tingkat kebermaknaannya baik yaitu $0,00(<0,05)$.

4) Korelasi variabel Kelompok Persepsi untuk pengalaman kerja di rawat inap berkoefisien 0,448 (lemah) tetapi tingkat kebermaknaannya baik yaitu $0,00(<0,05)$. 
Journal of Healthcare Technology and Medicine Vol. 6 No. 2 Oktober 2020

Universitas Ubudiyah Indonesia

e-ISSN : 2615-109X

5) Korelasi antara faktor Kelompok Kelamin dengan Kinerja sengaja tidak diproses karena jumlah frekuensi di antara 2 kelompok kelamin sangat senjang.

2. Analisis 3 variabel independen dengan konversi nialai skala interval Pengaruh Rasio Beban Fisik dengan skala interval terhadap Kinerja (CARE dengan skala interval), menunjukkan nilai skala korelasi Pearson sebagai berikut:

1) CARE dengan Beban Fisik berkorelasi di level 0,392 dan signikansi baik sebesar 0,001 $(<0,05)$. Pada proses uji regresi nilai korelasi yang sebaik itu disisihkan dari perhitungan karena nilai signifikansi regresinya terhadap CARE $>0,05$. (Nilai tersebut menerima hipotesa nol jadi disisihkan dari variabel regresi yang mampu memengaruhi)

2) CARE dengan Beban Psikologis memiliki nilai korelasi 0,515 (bernilai menengah /sedang dan tingkat signifikansinya $0,00(<0,05)$. RBM akan diikutkan berperan memengaruhi CARE dalam hitungan regresi.

3) CARE dengan (Fasilits dan Pelatihan Kerja dan lain lain) berkorelasi positif di level 0,558 dan dengan signifikansi $0,00(<0,05)$. RBF juga disertakan sebagai yang berpengaruh terhadap nilai CARE dalam analisis regresi.

3. Secara umum sudah ada kemajuan kinerna peningkatan mutu dari pelayanan oleh perawat dan bidan menurut indicator BOR yang diukur dalam periode pendek di akhir tahun 2018. Pada saat itu jumlah tempat tidur sebagai pembanding telah dinaikkan setingkat $30 \%$ tetapi BOR mereka turut meningkat sejalan dengan upaya mereka m3enjalankan program peningkatan mutu kinerja. Tidak mesti dapat dipastikan bahwa peningkatan kinerja hunian tempat tidur rawat inap hanya oleh karena peningkatan mutu pelayanan rawat inap, tetapi sewcara statistik fakta peningkatan kinerja itu terbaca beregresi positif dengan nilai-nilai variable independen yang ditingkatkan secara bertahap. Hitungan Regresi menyertakan peran dari 2 variable RBM dan RBF sebagai variable independen yang signifikan.

4 Hasil analisis Kinerja perawat/bidan di unit rawat inap menunjukkan bahwa kinerja pihak perawat lebih baik dari kinerja bidan. Perbedaan pendidikan profesi mereka turut memudahkan pihak perawat beradaptasi dengan pelayanan pasien umum di rawat inap sekalipun dalam waktu yang sama dibandingkan dengan bidan. Peran pelatihan untuk dapat memuluskan kinerja pelayanan kiranya dapat menjadi pemacu keterampilan semua mereka dapat meningkatkan standar mutu pelayanan. Di unit rawat inap. 
Journal of Healthcare Technology and Medicine Vol. 6 No. 2 Oktober 2020

Universitas Ubudiyah Indonesia

e-ISSN : 2615-109X

\section{DAFTAR PUSTAKA}

1. Jokowi. Jokowi: Revolusi Mental Nawacita, Jakarta. Jakarta; 2015.

2. Koentjaraningrat. Koentjaraningrat, Kebudayaan, mentalitas, dan pembangunan: bunga rampai. Gramedia Pustaka Utama, 1994. 1994.

3. Dnda Muhammad. PERKEMBANGAN MEA DI INDONESIA DAN DAMPAK GLOBALISASI ... .blogspot.com/.../perkembangan-mea-di-indonesi... Translate this page Jan 11, 2017 - Dhinda Muhammad Imanie (A1A514213). Kelas B. PROGRAM STUDI PEDNDIDIKAN GEOGRAFI. JURUSAN ILMU PENGETAHUAN SOSIAL. [Internet]. 2017. Available from: http://ckd.vacloud.us/rooms/kidney-info/topics/how-to-protectyour-kidneys/\#slide_2

4. Hans Selye. Stress Without Distress,Fishbein's Medical and Health Encyclopedia International Unified Edition Volume 20, HS Stuttman Inc, Westport Connecticut USA. Stutman USA; 1981.

5. Sopacua E. sebagaimana dimaksud dalamPancasila dan UUD 1945, Jakarta, , KARS dan Akreditasi Sebagai Upaya Peningkatan Mutu Pelayanan Https://media.neliti.com/..., 2006. 2010;

6. Kinayan NSG. the Influence of Thought and Feeling Factors, Personal References, Resources and Culture on Patient Satisfaction At Inpatient Wards of Delima Hospital Medan. 2017;1(107):1-10.

7. Parmenter D. Key Performance Indicators David Parmenter'sKey Performance Indicators (KPI): Developing, Implementing, and Using Winning KPIs [Hardcover](2010) [D., (Author) Parmenter] on .. 2010.

8. Notoatmodjo S. PENGARUH PERSONAL REFERENCE, THOUGHT AND FEELING ... https://e-journal.unair.ac.id/PROMKES/article/view/4470 Translate this page by A Nazira - 2017 - Cited by 4 - Related articles PENGARUH PERSONAL REFERENCE, THOUGHT AND FEELING TERHADAP KESEHATAN REPR. Jakarta: Rineka CIpta; 2006.

9. Singgih S. Statistik Parametrik, Uji Reliabilitas dan Validitas Pakai Alfa Cronbach, Elex Media Komputindo Gramedia Jakarta. Jakarta: Gramedia; 2000.

10. All G et. Organization Structure, Proceaa. 2006. 
Journal of Healthcare Technology and Medicine Vol. 6 No. 2 Oktober 2020

Universitas Ubudiyah Indonesia

e-ISSN : 2615-109X

11. Kinayan NSG. Profile RSU Delima Medan 2018. RSU Delima Medan; 2018.

12. ALL E et. The Effect of Workload on Occupational Stress, Subjective measures SWAT Developed by US Air Force download. NASA USA; 2015.

13. Joel. Vigilance Requires Hard Mental Work and Is Stressful, February 1, 8. Journal. 2008;

14. Head Up, Mentally, Healthy Workplace https://www.headsup.org.au/ healthyworkplaces/why-it-matters diunduh 1 Maret 2019. 2019.

15. Lucidchart. How to Build a Recruitment Process, creating-a-recruitment-process Learn the six steps involved in the recruitment process recruitment process is an organization-specific plan for finding new ... The Human Resources (HR) department of a company gene. https://www.lucidchart.com/; 2017.

16. Bandung DK. Rencana Strategis Rawat Inap RS Pem Kab Bandung 2018 ,. Bandung: http://www.bandungkab.go.id/arsip/pemkab-bandung-rencanakan diunduh 2019; 2018.

17. Tim Renstra. Tim Pelaksana, Reviu Renstra - RSUD Dr. Saiful Anwar, Jawa Timur. Jawa Timur: rsusaifulanwar.jatimprov.go.id; 2016.

18. Ario Rahadhi S. Program Studi Teknik Industri, Fakultas Teknik, Universitas Diponegoro. Email :ario.rahadhi@gmail.com; 2018.

19. Nunuk Trimumpuni. Analisis Pengaruh Persepsi Mutu Pelayanan Asuhan Keperawatan Terhadap Kepuasan Klien Rawat Inap di RSU Puri Asih Salatiga Program Pascasarjana Universitas Diponegoro Semarang 2009 [Internet]. Semarang: Universitas Diponegoro; 2009. Available from: http://ckd.vacloud.us/rooms/kidney-info/topics/how-to-protectyour-kidneys/\#slide_2

20. Esther CD. Hubungan Kelelahan Kerja Dengan Kinerja Perawat di Instalasi Rawat Inap RSU Pancaran Kasih GMIM Manado. Manado: RSU Pancaran Kasih GMIM Manado; 2018.

21. Rizky M. PT. Kimia Farma (Persero) Tbk. Watudakon, Jombang E-mail: rizkymaharja@gmail.com. Jombang: PT. Kimia Farma (Persero) Tbk.; 2015.

22. Dkk MMR. Prevalensi Gangguan Mental Umum Pada Dokter Rumah Sakit. 2016.

23. Darman Syarif. Teori-Teori Manajemen dan Organisasi Tentang Kinerja, theory manajemen dan organisasi.blogspot.com/2015/12/Kinerja. [Internet]. Plan4Bangkok. 2018. Available from: http://www.plan4bangkok.com/download.html 
Journal of Healthcare Technology and Medicine Vol. 6 No. 2 Oktober 2020

Universitas Ubudiyah Indonesia

e-ISSN : 2615-109X

24. Cokroaminoto. Faktor-faktor yang Memengaruhi Kinerja Individu Dalam Organisasi [Internet]. 2013. Available from: http://ckd.vacloud.us/rooms/kidney-info/topics/how-toprotect-your-kidneys/\#slide_2

25. Hersey, Paul dan Blanchard K. Manaje4men Perilaku Organisasi, Penda yagunaan Sumber Daya Manusia,, Mensintesiskan Teori Manajemen : Pendekatan Holistik, Kepemimpinan Situasional dan Motivasi, Penerbit Erlangga, Jakarta, 1982 hal 351 - 364. 1982.

26. Ikram M. Korelasi Perilaku Pemimpin dengan Komitmen Bawahan di Pemerintah Kabupaten - Kota Provinsi Gorontalo, Universitas Hasanudin, Makasar, digilib.unhas.ac.id. Gorontalo,: Universitas Hasanudin, Makasar; 2017.

27. Indoneiia P. Standar Praktik Keperawatan Indonesia -Tahun Persatuan Perawat Nasional Indonesia (PPNI) Pengurus Pusat PPNI, [Internet]. httSekretariat: J1.Mandala Raya No.15 Patra Kuningan Jakarta Tlp: 62-21-8315069 Fax: 62-21-8315070 Email: dppppni@yahoo.com, Web; http://www.inna-ppni.or.id Action Area; 2005. Available from: $\quad$ http://ckd.vacloud.us/rooms/kidney-info/topics/how-to-protect-yourkidneys/\#slide_2

28. Https://www.lucidchart.com. what-is-the-human-resources. https://www.lucidchart.com; 2017.

29. Adecco. Motivating Employees in the Workplace - , [Internet]. Plan4Bangkok. 2017. Available from: http://www.plan4bangkok.com/download.html

30. Hazel Richards. . "How to ensure the right people, with the right skills Employees- NHS Employers England North Action Area [Internet]. 2013. Available from: http://ckd.vacloud.us/rooms/kidney-info/topics/how-to-protect-your-kidneys/\#slide_2

31. Dkk HTF. Pengukuran Beban Kerja Perawat Menggunakan Metode NASA -TLX Di Rumah Sakit TLX Departemen Teknik Industri, Fakultas Teknik, Universitas Sumatera Utara USUFakultas Teknik, Universitas Sumatera Utara USU. 2008.

32. MEDAN RD. Profile RSU Delima Medan 2016-2017. 2017.

33. KARS DB and. Juknis-SIRS. Dirjen BUK \& KARS; 2011.

34. Rektor-Guru-Besar-Prof Nursalam Tentang CARE Dalam Keperawatan, Unair Surabaya (2014). Humas Ners (Surabaya); 2014.

35. Kho. Samuel. Cause and Effect Diagram, TQM An Integrated Approach, , hal 144. Kogan 
Journal of Healthcare Technology and Medicine Vol. 6 No. 2 Oktober 2020

Universitas Ubudiyah Indonesia

e-ISSN : 2615-109X

Page London; 2000.

36. Singgih S. Statistik Parametrik, Uji Reliabilitas dan Validitas Pakai Alfa Cronbach, Elex Media Komputindo Gramedia Jakarta 2000. Jakarta; 2000.

37. SPSS JI. Statistic Versi 23 IBM SPSS Statistics for Windows, Version 23: A Basic Tutorial | SSRIC https://ssric.org/node/582. 2013.

38. ANWAR H. Transformasi Data Ordinal Menjadi Interval Teknik Pengumpulan Data dan Skala Pengukuran.

39. Sugiyono P. Metode Penelitian Pendidikan, Pendekatan Kuantita. Bandung: Alfabeta; 2014.

40. Hadi PS. BL-1.897.METODOLOGI RESEARCH.PROF.Drs.SUTRISNO HADI $\ldots$ Yogyakarta: Univ Gajah Mada Yogyakarta; 1987.

41. Sellers J. Team Workload Questionnaire (TWLQ), Development and Assessment of Subjective Measure of a Team Workload, Master of Science in Apllied Psychology at University of Cantebury, New Zealand, Cateburry: Cateburry Universty; 2013.

42. Agung. Pengertian, Tutorial, dan Interpretasi Regresi logistik dengan SPSS. KONSULTAN; 2018.

43. Iman M. Pemanfaatan SPSS Dalam Penelitian BIeang Kesehatan \& Umum, Regresi Berganda Binary hal 141 - 147. Medan: Cipta Pustaka Media Medan; 2012. p. 141-7.

44. Hastono SP M. Analisis Data Pada Bidang Kesehatan,. Jakarta: PT. Raja Grafindo, Persada; 2016. 